\title{
Retinoblastoma pT2b TNM Finding v8
}

National Cancer Institute

\section{Source}

National Cancer Institute. Retinoblastoma pT2b TNM Finding v8. NCI Thesaurus. Code C140719.

Tumor invasion of stroma of iris and/or trabecular meshwork and/or Schlemm's canal. (from AJCC 8th Ed.) 